\title{
Archaeology and Heritage Management in the Maya Area: History and Practice at Caracol, Belize
}

\author{
Arlen F. Chase ${ }^{1, *(\mathbb{D})}$, Diane Z. Chase ${ }^{2}$, John M. Morris ${ }^{3}$, Jaime J. Awe ${ }^{4}$ and Adrian S. Z. Chase ${ }^{5}$ (I) \\ 1 Pomona College, 420 N. Harvard Ave., Claremont, CA 91711, USA \\ 2 Vice President, Academic Innovation, Student Success, and Strategic Initiatives, Claremont Graduate \\ University, 150 E. 10th St., Claremont, CA 91711, USA; diane.chase@cgu.edu \\ 3 Director, Institute of Archaeology, Museum and Archaeological Research Centre, Culvert Road, \\ Belmopan, Belize; john.morris@nichbelize.org \\ 4 Department of Anthropology, Northern Arizona University, PO Box 15200, Flagstaff, AZ 86011, USA; \\ jaime.awe@nau.edu \\ 5 Department of Anthropology, School of Human Evolution and Social Change, 900 Cady Mall, Arizona State \\ University, Tempe, AZ 85281, USA; aschase1@asu.edu \\ * Correspondence: arlen.chase@pomona.edu
}

Received: 23 May 2020; Accepted: 10 June 2020; Published: 11 June 2020

\begin{abstract}
Archaeology and heritage management in the Maya area have developed differently in the various modern-day countries that make up ancient Mesoamerica. In the country of Belize, heritage management has been conjoined with archaeology since at least the late 1970s. Long-term projects, such as the 1985-to-present archaeological investigations at the ancient ruins that comprise the immense city of Caracol, Belize, demonstrate the evolution of heritage management. This abandoned metropolis has also been the location of concerted stabilization and conservation efforts. Research and heritage management efforts at this urban center have been coordinated and intertwined since the project's inception. This article contextualizes the long-standing relationships between archaeology and cultural heritage as it has been practiced at Caracol, Belize within the broader field of Maya Studies.
\end{abstract}

Keywords: heritage management; collaborative research; Maya archaeology; consolidation; stabilization; looting

\section{Introduction}

The management of the heritage of ancient Mesoamerica is operationalized in different ways in the various countries that constitute the culture area. Belize, El Salvador, Guatemala, Honduras, and Mexico all contain ancient Maya sites but have different laws governing archaeological practice related to these past remains. In some countries, heritage is used to instill and support a sense of nationalism in a diverse population; in others, the projection of national heritage is a source of controversy among ethnic groups. No matter the case, archaeology figures prominently in documenting and building heritage, both past and modern. This article contextualizes heritage management at Caracol, Belize by providing a historical frame of reference for this ancient Maya site. It chronicles the efforts that went into the conservation and stabilization of these ruins for touristic purposes and also places these efforts within broader policy issues in Mesoamerican archaeology. Caracol has always been viewed by the country of Belize as their anchor site for both world heritage status and for Mundo Maya tourism, and balancing these two objectives has presented challenges for the site's heritage management. 


\section{Background}

Any history of heritage management in the Maya area (Figure 1) should consider the activities of some of the earliest Spanish priests that set foot in Mesoamerica. Much of the rich cultural heritage of central Mexico was preserved in the writings of Bernardino de Sahagun [1] in the Florentine Codex, but in the Maya area, Diego de Landa [2] gathered together the written heritage of the native Maya and burned their paper books (codices) and wooden religious images in a great bonfire- $\mathrm{a}$ formal attempt to destroy ancient Maya heritage and ways of life. His subsequent record about Maya culture and history was an atonement for his activities in the Yucatan, written in Spain with access to other colonial descriptions; while not replacing the works he destroyed, his written report remains a major reference for the ancient Maya [3,4] (pp. 362-363). In general, however, the initial Spanish settlers in the Maya area attempted to convert the Maya to Christianity and concomitantly to erase their ancient heritage, first through policies involving population movements and the establishment of encomiendas [5] and subsequently through the removal of perceived pagan or otherwise offensive Precolumbian images, while at the same time imposing European mores and values. Thus, when Empress Carlotta of Mexico, cousin of Queen Victoria of England, visited the site of Uxmal in November 1865, the local officials made a concerted effort to remove all ancient Maya phallic images that had once existed at the site (phallai were used as gutter spouts on buildings and were also placed vertically as stelae; see [6-8] (p. 319)).

The value of the ancient past was seized upon in Mexico as a way of uniting its many native populations; ancient architectural structures were viewed as monuments to be celebrated and that could be used to foster nationalism [9] (p. 191). This is evident in the massive effort that went into the stabilization of the Pyramid of the Sun at Teotihuacan under the guidance of Leopoldo Batres in honor of the first century of Mexican independence. In order to move the earth and supplies necessary to undertake this task, a railway was built to the Pyramid of the Sun [10] (p. 11). In Mexico, heritage management has thus long been tied to the creation of a national identity [11]; the stabilization of Teotihuacan's largest pyramid was the forerunner of subsequent Mexican policy focused on the preservation of its sites for both touristic and nationalistic purposes [12].

Maya archaeology has a varied history of heritage management and site stabilization that in some cases corresponds with national boundaries. Early research projects in the Maya area had different track records with regard to site preservation. The activities carried out by archaeological projects associated with the Carnegie Institution of Washington (CIW) highlight contrasting approaches to this issue [13] (p. 273). The initial CIW project at Uaxactun, Guatemala (carried out from 1924 to 1937), left excavations open and largely removed the central palace (and other structures) of that site during the course of its study [14]. In contrast, the CIW project at Chichen Itza, Mexico (carried out from 1924 to 1936), focused on the conservation of select structures under the guidance of the lead researcher Sylvanus G. Morley. Thus, multiple buildings-the Castillo, the Temple of the Warriors, and the Mercado-were all stabilized under the watchful eye of the project. Part of the difference in approaches was likely due to the remoteness of sites and proximity of modern populations. Uaxactun was located deep in an uninhabited jungle in an area where supply runs were more difficult, whereas Chichen Itza was surrounded by population and already had recognized touristic value by the time that the CIW established their project at the site. Yet, the stabilization of Chichen Itza had even broader ramifications than heritage management, helping to define perceptions of both ancient and modern Maya [15]. The recognition of a past relationship between Chichen Itza and Tula in central Mexico $[16,17]$ also served nationalistic purposes. Subsequent stabilization of Tula magnified the similarities between the two sites; in fact, there has been a strong suggestion that the Tula stabilization process created features similar to Chichen Itza where none had existed earlier $[18,19]$. Regardless of intent, the similarities between these two spatially distinct sites were also points that could be utilized to emphasize the shared heritage of the Mexican people. 


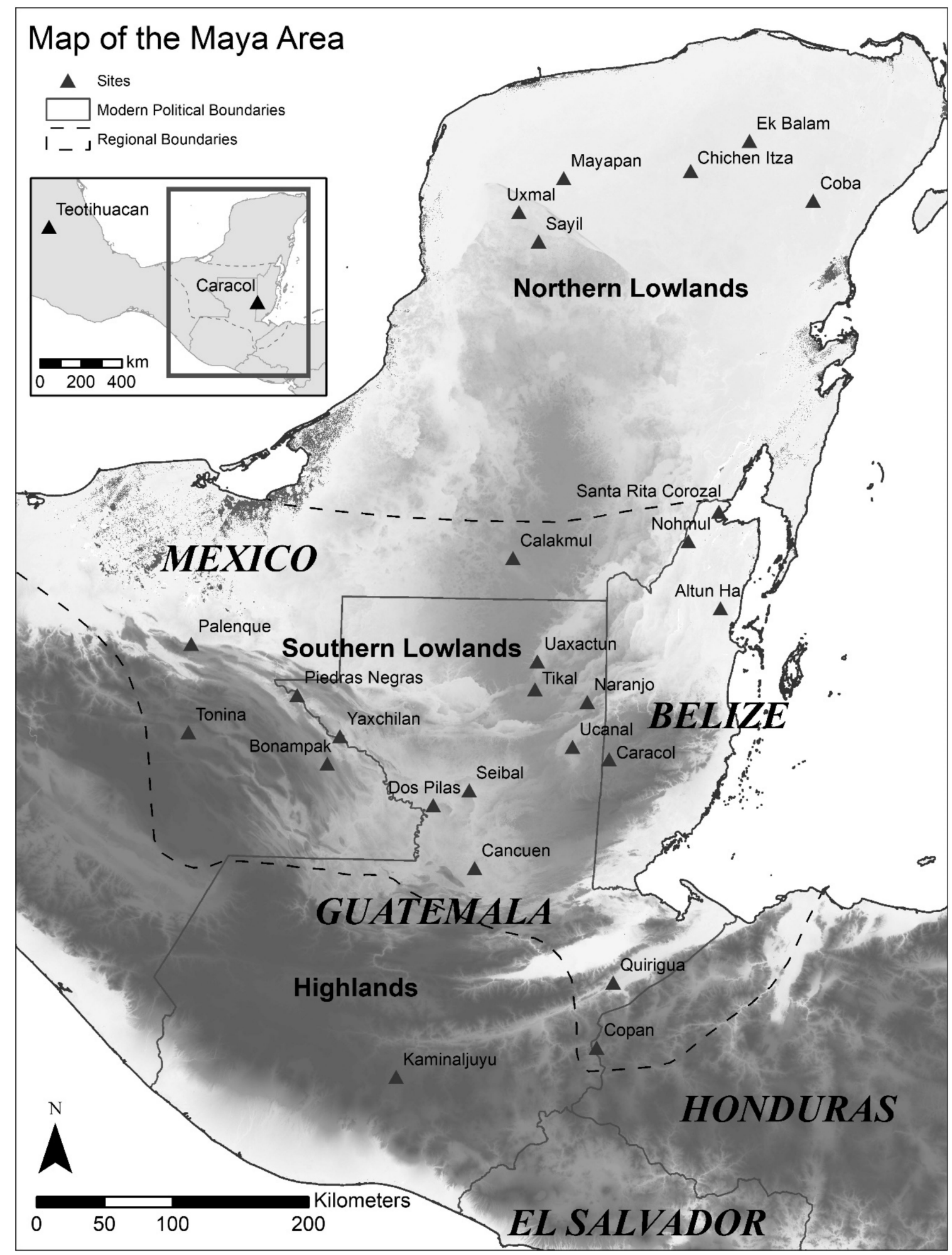

Figure 1. Map of the Maya Area with select sites in the southern lowlands indicated.

While archaeology in the Northern lowlands at Chichen Itza incorporated stabilization and preservation, Maya archaeology in the Southern lowlands did not initially have this focus. As already mentioned, at Uaxactun, later buildings were removed to expose earlier ones and to determine complete architectural plans and sequences [20] with open excavations not being backfilled [13]. Early excavations at Piedras Negras, Guatemala likewise did not focus on backfilling. The University Museum of the University of Pennsylvania carried out an archaeological project at that remote site 
from 1931 to 1939; conservation and stabilization were not part of the research design (see photos in [21]). A more recent (1997-2000) archaeological project at Piedras Negras attempted to remedy this through the "stabilization of structures and trenches left exposed" [22]. For any number of Maya archaeological projects through the late 1970s backfilling excavations was not part of standard practice, especially when research took place in inaccessible and largely uninhabited areas as was the case for much of the Maya Southern lowlands. However, a change in heritage preservation practice can be seen in the excavations carried out at Tikal, Guatemala by the University Museum of the University of Pennsylvania between 1956 and 1969 .

A major focus of research for the University Museum Tikal Project was the North Acropolis of that site, eventually published in a six volume set by William R. Coe [23], the director of the investigations. Excavation of the North Acropolis at Tikal included a $10 \mathrm{~m}$ wide trench that penetrated this architectural complex down to bedrock and had deep side tunnels to other earlier, buried structures. Not only had Tikal been selected to highlight the research carried out by The University Museum, but the Guatemalans also wanted the site to be developed as a way of attracting tourists to Guatemala to enhance that country's economy. As the North Acropolis formed the northern side of the principal plaza at Tikal, its preservation became essential for Guatemalan tourism. However, by 1966, the $10 \mathrm{~m}$ wide trench was collapsing, and, before the end of the University Museum Tikal Project, the axial investigation needed to be backfilled so that tourists could appropriately visit the Tikal epicenter. Most of the debris from the North Acropolis trench had been removed some distance and would have required a substantial amount of labor to reclaim. The eroded central pyramid, Structure 5D-33-1st, located at the south (and front) side of the massive trench, was selected for total excavation and as the source for backfilling material for the excavation. The dismantling of this pyramid down to an earlier construction and its use to infill the axial trench through Tikal's North Acropolis were justified as an exercise to understand how the pyramid had been built and was sanctioned by Guatemala's IDAEH, which regulated archaeology in that country [23,24]. But, heritage management decisions made in the 1920s and 1930s when northern Guatemala was not a major touristic location were not as easily replicated in the 1960s, and a major debate ensued over the complete excavation and removal of the latest version of Structure 5D-33 and its use as backfilling material [24-26], in essence turning the issue of site preservation and heritage into an ethical conundrum.

We faced a somewhat similar challenge in 1985 during the first formal field season of the Caracol Archaeological Project (1985-present; http://www.caracol.org) in Belize. The central architectural complex at Caracol, named "Caana" or "Sky Place" [27], had seen two of its three summit pyramids badly looted. Structure B19, the northern structure, had been tunneled into from its northern side and Structure B20, the eastern building, had a massive trench through its front and had been deeply tunneled into from its eastern side, revealing three looted tombs [27] (figs. 4 and 5)] [28]. Investigations in the trench that bisected the front of the summit building revealed an earlier structure that was in a fairly good state of preservation and that had scenes of graffiti on its inner walls, including one of an elite Maya individual being carried on a palanquin [29] (fig. 4.12)]. The then archaeological commissioner for Belize, Harriot Topsey, upon a visit to the site in 1985 briefly discussed the possibility of removing all of Structure B20-1st to expose the earlier building for viewing. However, remembering the ethical dilemma and castigation suffered by the Tikal archaeologists, we all agreed that a better solution was to not take such a path, and today Structure B20-1st is stabilized (thanks to both the efforts of the United States Agency for International Development (USAID) and the Tourism Development Project (TDP) stabilization projects noted below) and provides the full Late Classic vista for Caracol's Caana summit. The consensus reached in 1985 helped us to understand better the broader implications for archaeological research beyond providing just scholarly data for interpreting the past. It placed us squarely in the middle of considerations of how to present the physical past to the modern world in the context of goals that were not only focused on basic research but also on economic development and tourism. This experience also helped highlight the importance of being simultaneously involved in both the archaeology of and the conservation and/or heritage management for a site-something that 
in the early 1980s had been long separated in the Southern Maya lowlands (where the archaeologist carried out the research and the country of origin undertook the stabilization).

By the 1980s, Maya archaeology was rapidly evolving in terms of heritage management. Mexico was assessing researchers with a 15\% overhead fee on archaeological projects in order to support the conservation and stabilization of that country's sites for tourism. By the mid-1980s, archaeological excavation permits in the country of Belize mandated that all excavations be backfilled or stabilized, changing older archaeological policies that had been established by the British Colonial Government. As colonial British Honduras, researchers in Belize were accorded $50 \%$ of all finds to be curated and/or displayed in their home institutions; this is how The University Museum in Pennsylvania ended up with a large collection of carved stelae and altars from Caracol in 1953. However, this colonial practice of partage finally came to an end [30] (p. 281), and Belize changed its policies to make clear that archaeological materials were national heritage, mandating that all key finds be turned over to the then Department of Archaeology.

Belize followed Mexico's lead in assessing a 15\% stabilization/consolidation fee on all archaeological projects within the country [30]. When this fee was first proposed by the Belize Department of Archaeology, there was grumbling from some of the senior Mesoamerican archaeologists who were then working in Belize. These complaints reached the United States National Science Foundation (which had funded some of their research). Thus, in 1986, the National Science Foundation (NSF) sponsored a gathering during the American Anthropological Association meetings in Washington, D.C. between then Belizean archaeological commissioner Harriot Topsey and all of the archaeologists who were working or had recently worked in that country. With everyone seated around a large table, the meeting was fairly short. At the head of the table, Topsey looked at the assembled archaeologists, announced that Belize was instituting a 15\% surcharge for consolidation of ancient ruins, and asked if anyone had any comments. No one said a word. The silence was broken by John Yellen, who handled archaeological funding for NSF, when he announced that the National Science Foundation would respect the $15 \%$ surcharge by Belize in any grants as a valid consolidation/conservation expenditure.

\section{Caracol, Archaeology, and Stabilization: A Brief History}

The formal investigations of the Caracol Archaeological Project began with two preliminary trips to the site in 1983 and 1984, with annual archaeological field seasons commencing in 1985 [28,31,32]. To a large extent, archaeological experiences at Caracol mirror the already changing field of Maya archaeology and the redefined relationship that Maya archaeology had with heritage management [33]. While always a research project, the Caracol Archaeological Project embraced stabilization efforts early in its history, beginning formal consolidation work on the northern building in the A Group in 1988 (Figures 2 and 3). Archaeological heritage management involves conservation both for stabilization, making sure that something is physically secure or stable, and for tourism, ensuring that what is stabilized can, first, withstand repeated human contact and, second, enhance local economic development. Conservation for tourism requires significantly more expenditures and effort than conservation for stabilization. Given national goals related to tourism, the conservation of ancient buildings usually involves more than cursory stabilization, and this was in fact the case at Caracol. 


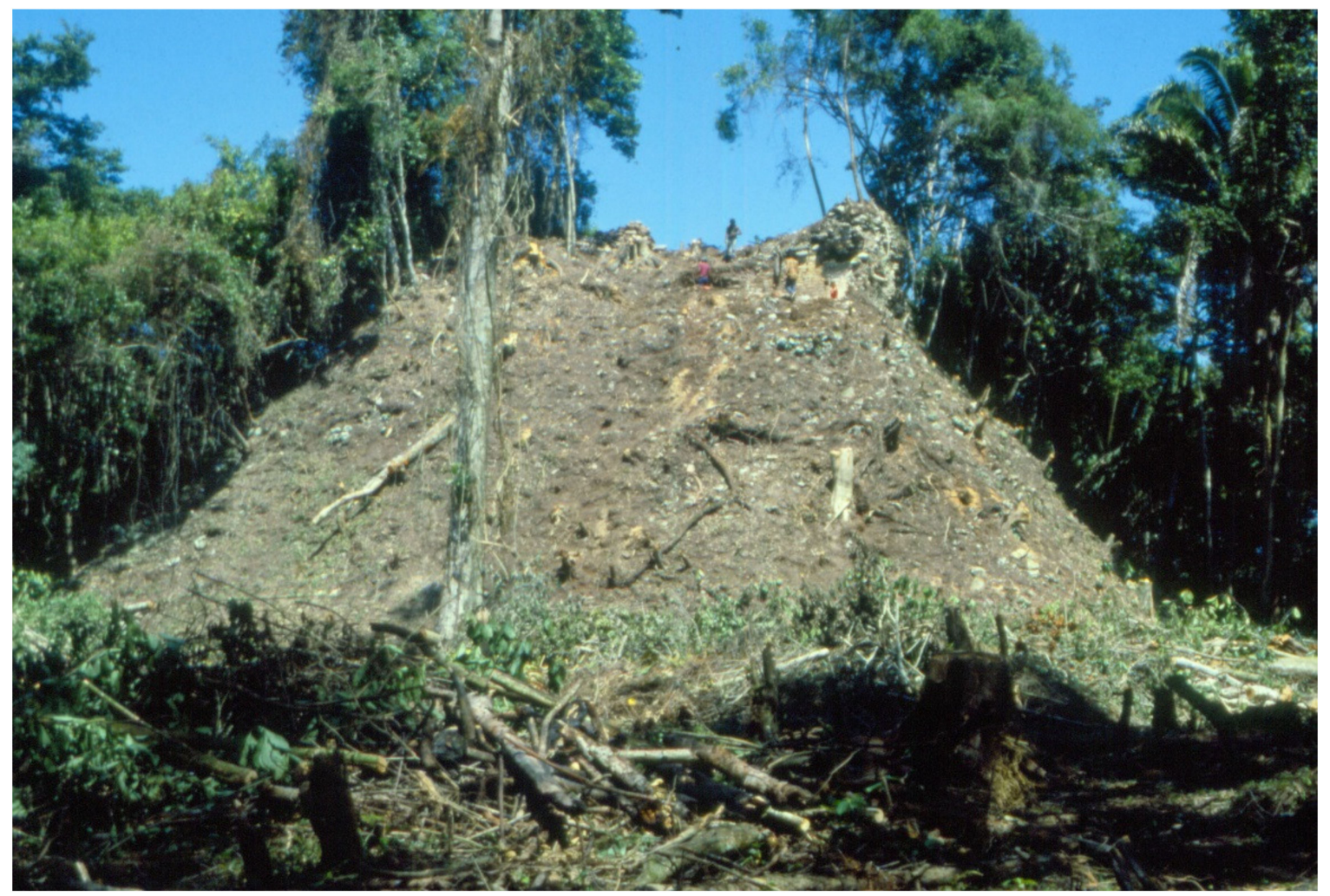

Figure 2. Caracol Structure A3 in 1986 before excavation (looking north).

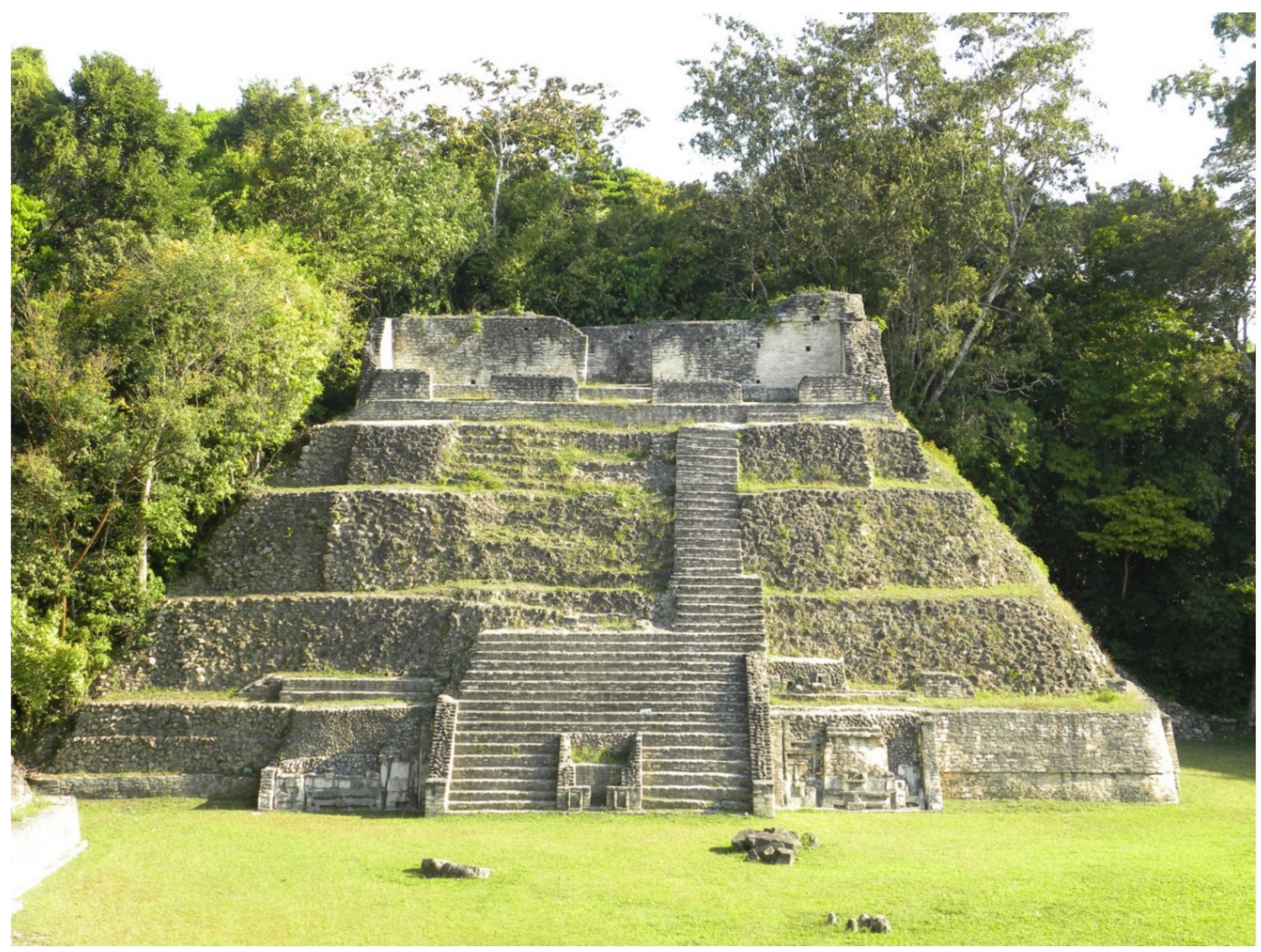

Figure 3. Caracol Structure A3 in 2011 after further stabilization by the TDP (looking north). 
Conjoining archaeology, stabilization, and tourism management at a site can be a useful iterative process. Stabilization permits safe tourism; archaeology provides information that encourages touristic visitation; and, archaeological research engagement in stabilization helps ensure accurate consolidation efforts. This interactive cycle is one that has, in fact, been used successfully at Caracol and is evident in our research and conservation strategies. Between 1985 and 1989, excavation focused on re-excavating looted structures and testing buildings in the site epicenter to establish a basic chronology; it also involved carrying out the first settlement pattern program in the southeastern part of Caracol to get a sense of city size and composition. Initial stabilization focused on Caracol Structure A3, one of the more accessible buildings in the site epicenter. This early work made clear that a combined research and stabilization program could provide key evidence on Terminal Classic (800-900 CE) site occupation in the epicenter as well as provide areas were visitors could safely visit the site. Thus, from 1989 to 1993, sponsored by the United States Agency for International Development (USAID) and the Government of Belize (GOB), a conjoined research and conservation project permitted the recovery of data pertinent to the Caracol's epicentral development and abandonment and stabilized a series of buildings in the downtown area $[27,34,35]$. In order to place these data in broader perspective, from 1994 to 2000, archaeological efforts focused on carrying out settlement pattern work in the northeastern and southwestern sectors of Caracol [36], again in an attempt to measure city size and better define its composition [32]. Conservation of buildings in these areas did not make sense, given the difficulties in providing long-term security and in conducting stabilization due to a lack of nearby roads and water.

During a second formal conservation effort from 2000 to 2004 by the Tourism Development Project (TDP), sponsored through the Government of Belize and run in conjunction with the Institute of Archaeology, the research project moved back into the epicenter of the site in support of these activities [37]. Following this stabilization cycle, archaeological work sought to better define Caracol's past social composition through examining a series of residential areas throughout the site [32,38], while also testing specific buildings and the associated plazas of various epicentral groups. The Northeast Acropolis, immediately east of Caana, was intensively investigated and was physically stabilized in conjunction with the Institute of Archaeology in 2011 [39]. Thus, the archaeological research has not only produced significant knowledge about Caracol's past, but has also articulated with the formal consolidation efforts and ever-increasing tourism. Extensive publication of the research results also helps to promote public interest in visiting the site, which helps drive Belize's economic development.

Over three decades of active archaeological investigation at Caracol have demonstrated how important the site is to any understanding of the Maya past. Not only is Caracol a massive urban city (Figure 4) [40-42], but it exhibited long-term relationships with people from other parts of Mesoamerica and the Maya area. An individual, potentially from the site of Teotihuacan based on artefactual materials and mortuary pattern, appears to have married into an elite family and was living at Caracol in the early part of the fourth century; the burial of this individual, dating to approximately A.D. 350, was recovered in Caracol's Northeast Acropolis plaza [39]. Connections with other close and distant Maya sites are found in epigraphic texts. Caracol apparently contributed the founding ruler for the site of Copan, Honduras in A.D. 435 [43,44]. Two of Caracol's greatest rulers, Yajaw Te' K'inich and K'an II, were buried in the North Acropolis at Tikal [32] (p. 219) [45], signaling the impact that successful warfare could have on the Maya political order [46]. Research also documents some ways that Caracol may have been unique. During the Late Classic period, Caracol practiced an enlightened form of social practice, known as "symbolic egalitarianism", where most of the populace had access to the same quotidian, prestige, and ritual items [32] (pp. 215-216) [47]; this led to the growth of a large middle status level $[48,49]$ that was facilitated by the site's market system [50-52] and easy access to water within household reservoirs $[53,54]$. The site organization with its dendritic causeway system, low-density urbanism, and agricultural terraces provides an ancient model of a walkable green city [55]. Finally, the collapse of Caracol again reveals the site's widespread interactions with other parts of Mesoamerica [35,56]. As such data about the site reaches not only academic audiences, but also public ones, the research can drive tourism and increase the need for heritage management. 


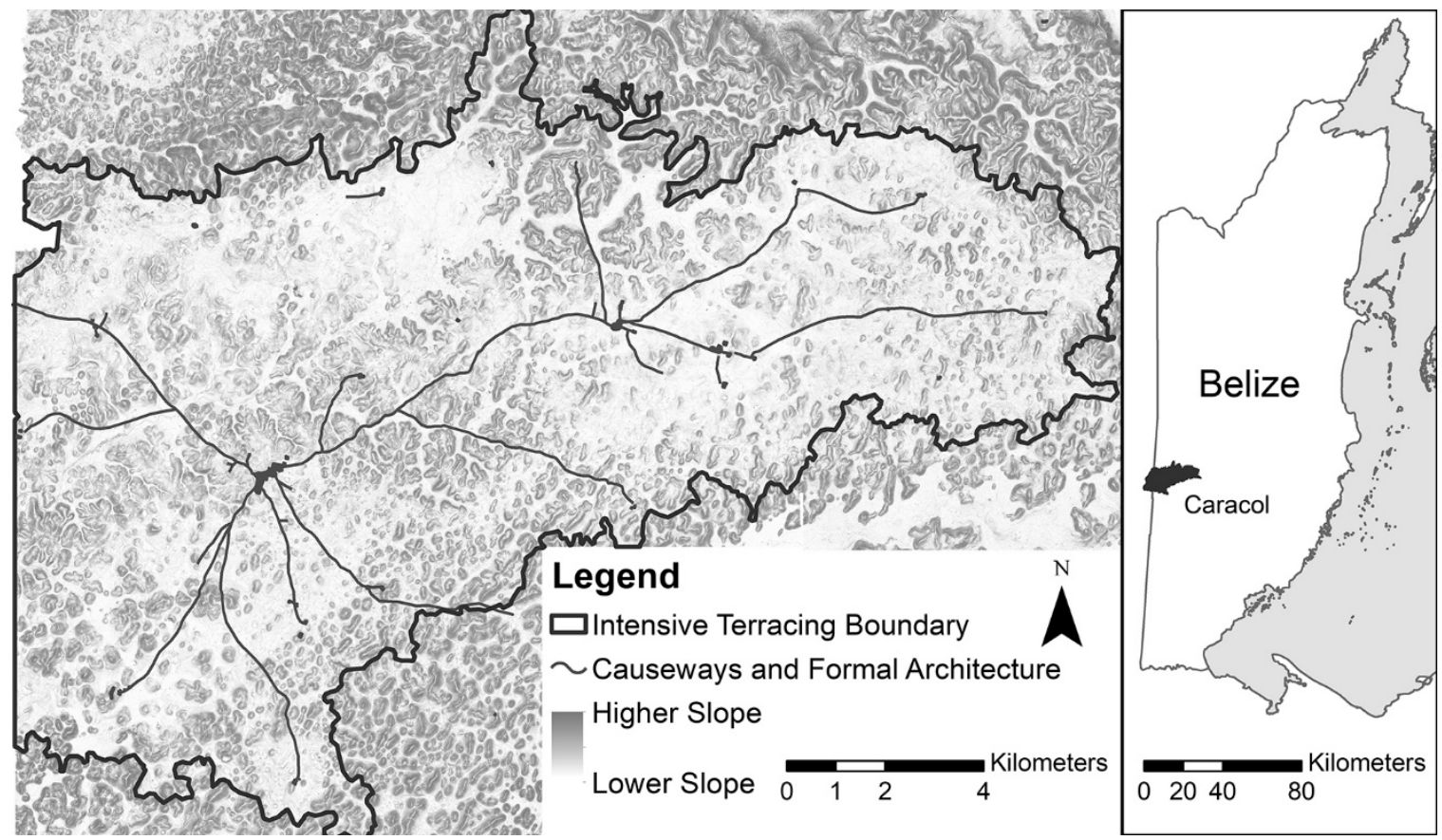

(after Chase, A.S.Z., et al. 2020 fig. 2)

Figure 4. The ancient city of Caracol, Belize shown against the modern country of Belize.

The support of long-term archaeological projects, like the one at Caracol that has conducted 36 consecutive field seasons, is not easy to accomplish. Assuring continued funding for research at a single site can be difficult [57], but it has been possible at Caracol because of the ability to establish different research designs over time and the fact that these different programs of research often evolved into new and interesting questions that were of interest to the general field of Maya studies [32]. Equally important has been the willingness and interest of both the lead archaeologists and the heads of the Belize Institute of Archaeology in cooperating and planning the process of conjoining research and heritage management.

\section{Caracol, Archaeology, and Stabilization: United States Agency for International Development (USAID)}

In the late 1980s, USAID was still operating throughout Central America and had provided funds to the development of Copan, Honduras in the late 1980s. Seeing that USAID had provided funding for archaeological research and stabilization in Honduras [58] (p. 20), the Caracol Archaeological Project approached USAID in Belize in 1987 about the possibility of funding for Caracol's touristic development. While the first response by the USAID office was negative, a new US ambassador in Belize (with an MA in Cultural Anthropology) helped turn USAID funding into a reality.

At the time that the USAID funding was provided in 1989, almost all tourists to Belize were either drawn to the cayes and the natural resources provided by the barrier reef or were passing through the country from Mexico on their way to Guatemala and that country's archaeological ruins. The proposed USAID funding was seen as a potential avenue for encouraging tourists to overnight in the Belize interior and thus contribute to the country's economic development. The USAID funding was tied to direct support from the Belize Government. The bulk of the funding for the first two years of stabilization came from USAID with the Belize Government providing progressively more in years 3 and 4; year 5 consisted of funding from the Belize Government alone. The overall goal of the USAID-supported Caracol Archaeological Project was to assure that there would be several architectural complexes in the epicentral part of the site (Figure 5) that visitors could see as a first 
step in drawing tourists into the interior of Belize. Initially, USAID wanted to know whether they should first spend money on a road to Caracol or on the site itself. While the road would have made the investigations easier and have saved a lot of wear and tear over the years in terms of spent and broken vehicles, it made no sense to fix the road if there was nothing but jungle to see at the end of the drive. The Caracol Archaeological Project therefore opted for site development and provided a plan to USAID that focused on three specific vistas that could be appreciated from ground level without having to climb pyramids: a front view of Caana (Figure 6), a rear view of Structure A6 (the Temple of the Wooden Lintel), and a front view of the South Acropolis (at the time gutted with open excavations from earlier investigations undertaken in the 1950s by A. Hamilton Anderson [59,60], the first archaeological commissioner of Belize). To attain these goals, we would first carry out the excavations of these locations and then supervise their stabilization with the support of Institute of Archaeology specialists, according to established practice in Belize. While each of these locales were indeed foci for USAID conservation, stabilization also was carried out on the summit building that comprised Structure A3 in the A Group, as well as on Structures A38 and A40 in the Central Acropolis (Figure 7). This plan of action not only produced solid archaeological evidence for the use, construction, and abandonment of Caracol's palaces and temples but also stabilized key structures.

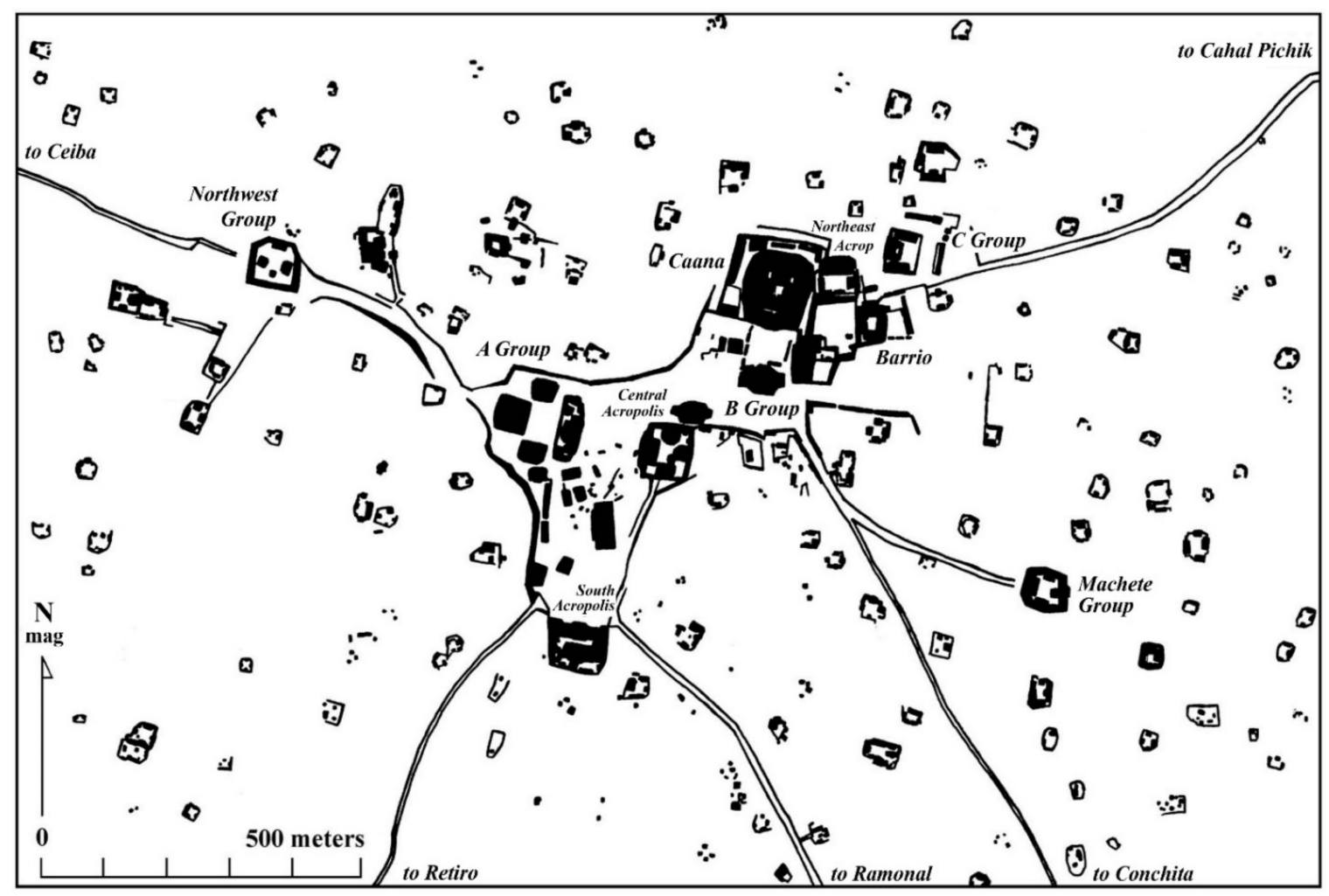

Figure 5. The epicentral buildings of Caracol, Belize (after [32] fig. 2). 


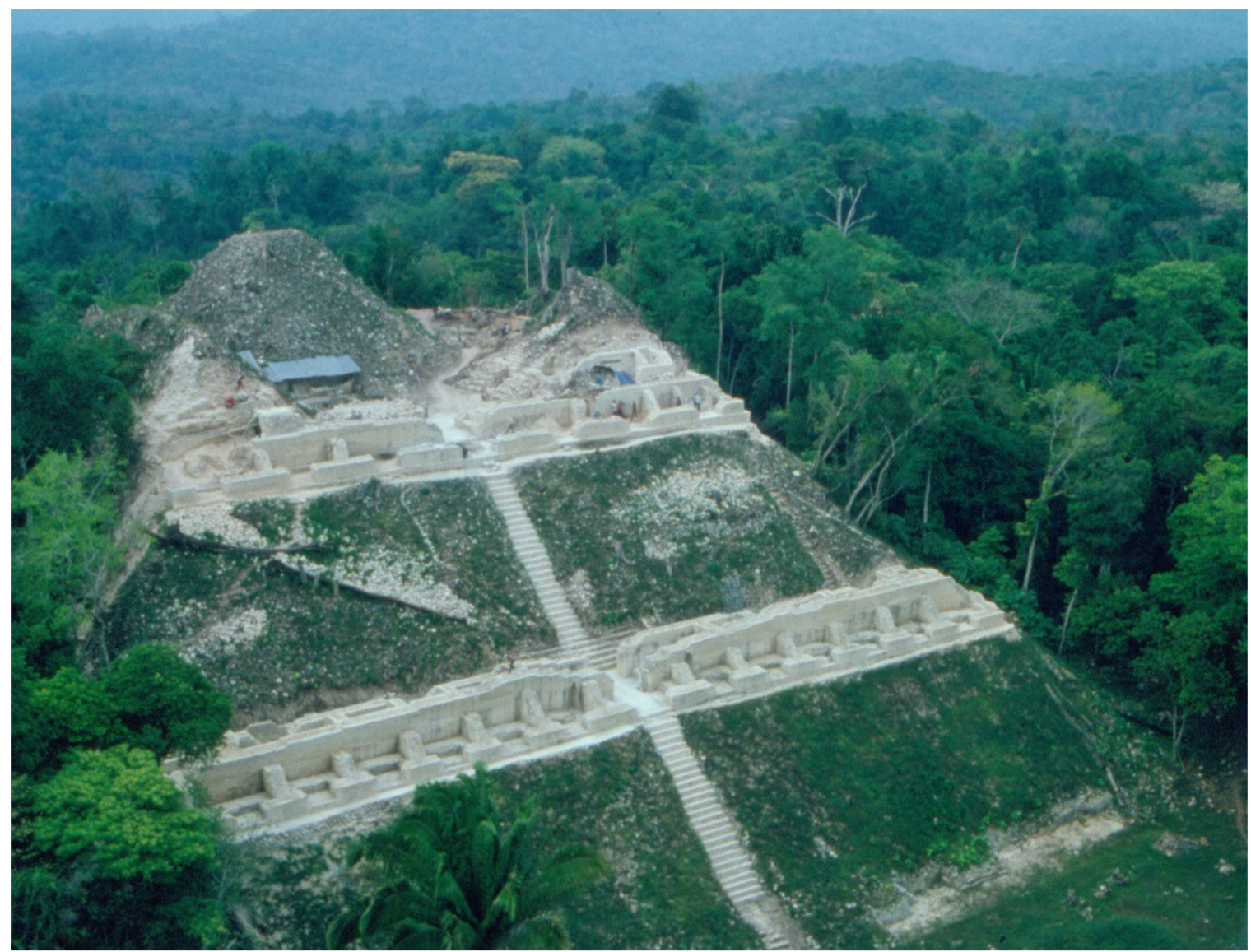

Figure 6. The USAID stabilization of the Caana architectural complex at Caracol, Belize in 1993.

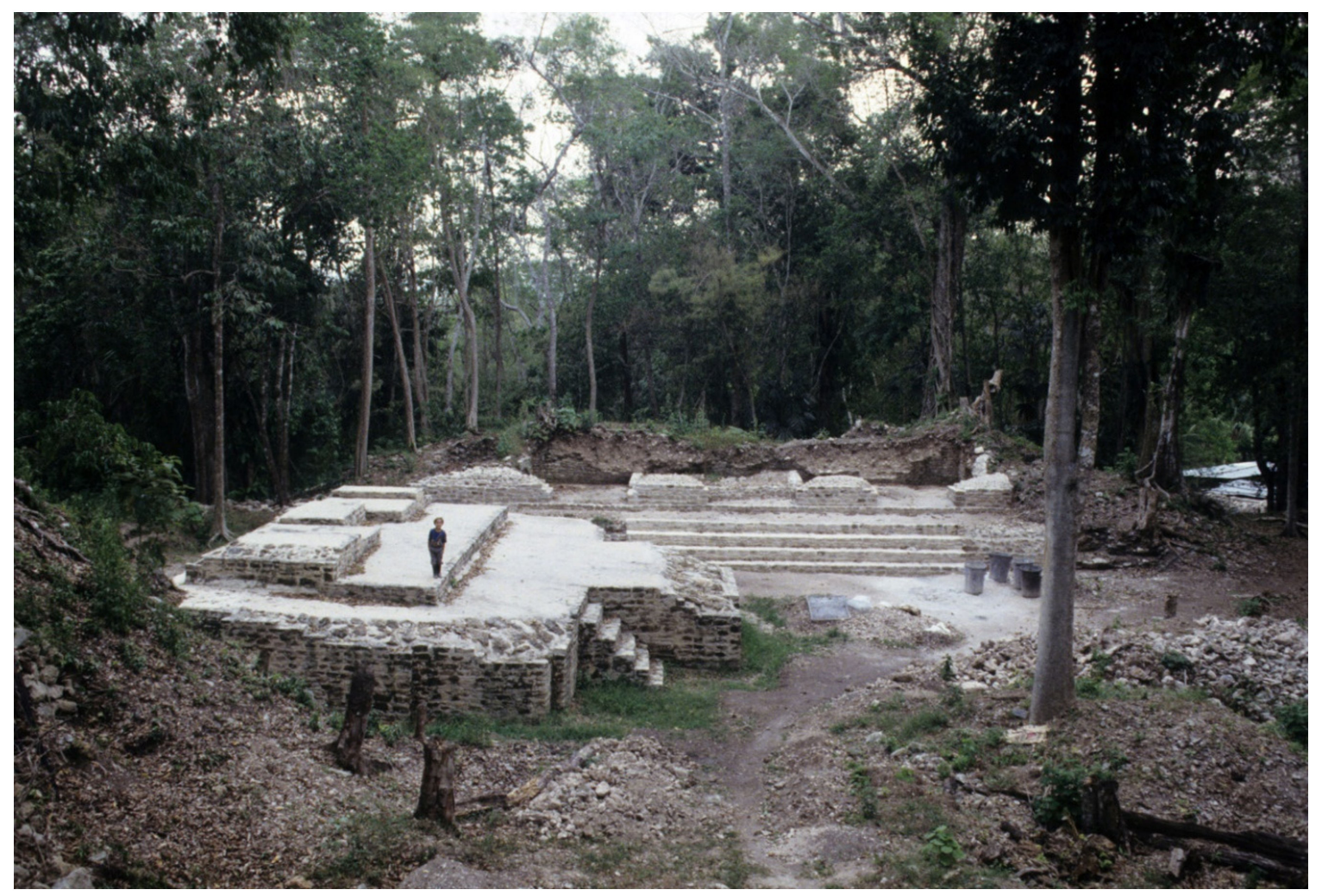

Figure 7. Caracol Central Acropolis stabilization undertaken by the USAID efforts (looking south). 
To stabilize excavated buildings, large amounts of lime and cement needed to be trucked into the site and clean marl fill and cut stone needed to be stockpiled. Luckily, the marl and cut stone were byproducts of excavating the once vaulted stone architecture in the site core. Thus, the only other thing needed was water, which was pumped from the Caracol A Group Reservoir. Using a standard mix of cement (1 part), lime (1 part), marl (3 parts), and water (as needed), the stabilization of the epicentral structures proceeded using the still extant ancient architecture as a guide (Figure 8). In this way, the epicentral structures of Caracol were transfigured into some sense of their former selves and also "tourist-proofed" so that they would not fall apart under the onslaught of visitors or be a danger to them. While the project supervised most of the stabilization in concert with the excavation of the buildings, specialists were also required. Thus, when a lintel was needed over the front doorway for the Temple of the Wooden Lintel (Structure A6), a zapote-wood beam was cut to specification and installed by the Institute of Archaeology's head stabilizer. While access to Caracol was still difficult because of the unfinished road, the stabilization work, television shows, and continuous publication of the archaeological research through the 1990s resulted in an upsurge in tourism. This increased tourism meant that earth-moving equipment was occasionally placed on the road to facilitate touristic access, drawing attention to the need for a road that could be used throughout the year, including the rainy season.

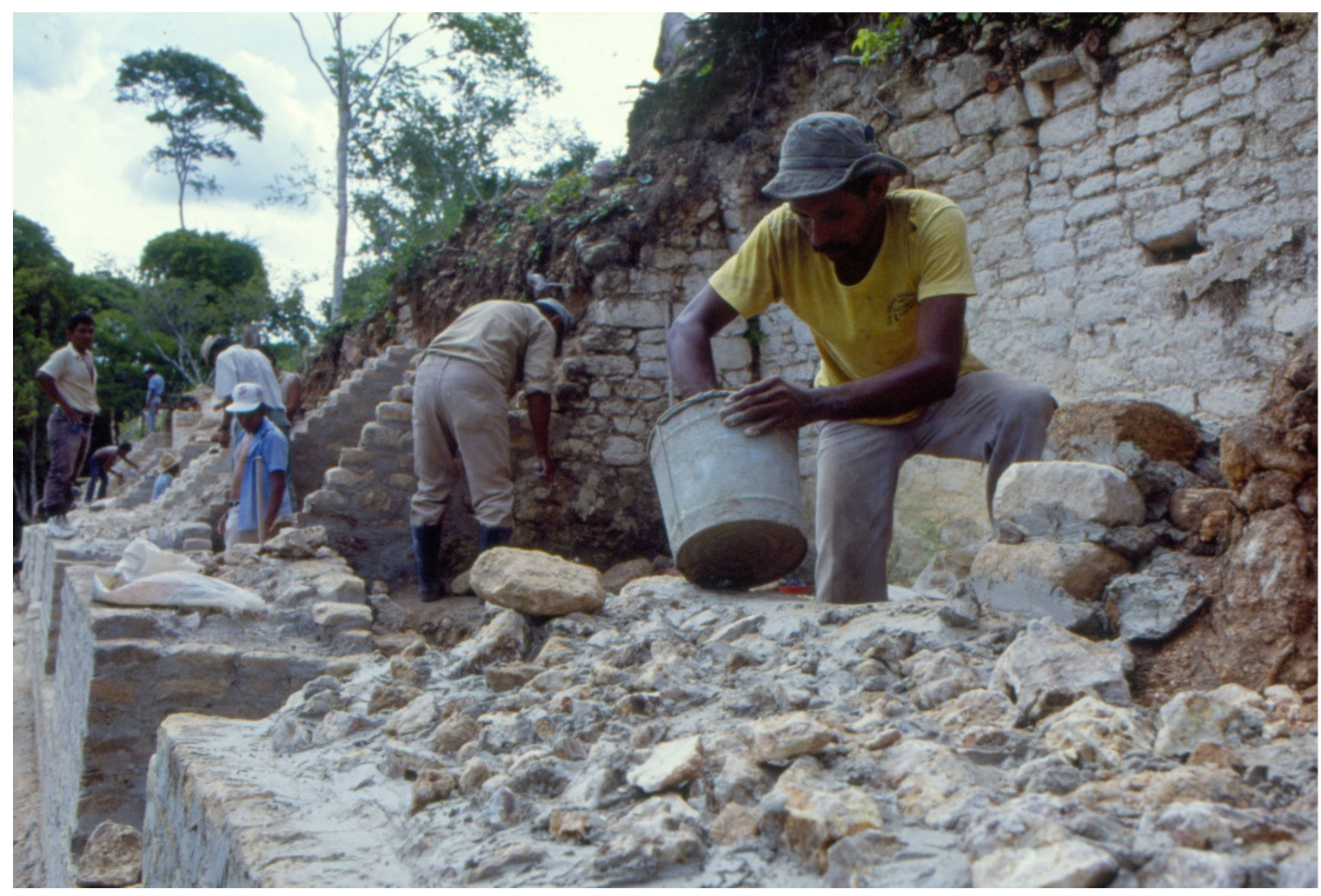

Figure 8. Stabilization being undertaken on the front face of Caana by the USAID efforts.

After the five-year USAID-Government of Belize stabilization project, the Caracol Archaeological Project continued to work closely with the Institute of Archaeology. In 1998-1999, the Institute constructed an on-site museum and visitor center just east of the site's epicentral architecture. This small exhibition hall is accessed by all tourists and sightseers to Caracol either at the beginning or end of their site visitation. The visual panels and artifactual displays that were installed in this on-site museum were undertaken by the Caracol Archaeological Project in concert with the Belize Institute of Archaeology (the images used for the installed panels may be viewed at https://www.caracol.org/dig/ virtual-museum/). This immediately foreshowed Belize's Tourism Development Project at Caracol 
and, again, a shift in research focus by the Caracol Archaeological Project back to the site epicenter to work with these stabilization efforts.

\section{Caracol, Archaeology, and Stabilization: Tourism Development Project (TDP)}

Following the initial USAID funding for Caracol, the Belize Government embraced the use of development funds to build archaeological infrastructure for tourism as a way of driving the economy of the county. In particular, the Belize Government partnered with the Inter-American Development Bank (IDB) and the World Bank to obtain funding for building their tourism infrastructure. After a series of consultants for these various funding agencies had completed their studies, the IDB provided the Belize Government with a loan for improving the road to Caracol and for also carrying out more stabilization not only at that site but at other archaeological sites throughout the country of Belize. This effort, which lasted from December 2000 through November 2004, was also seen as a way of providing employment opportunities to local constituents, much like the Works Project Administration in the US had used archaeology [61] during the Great Depression.

While the Caracol Archaeological Project continued with archaeological investigations at the site, the Tourism Development Project undertook stabilization of buildings previously investigated by the Caracol Archaeological Project, as well as in other buildings throughout the site epicenter. These new efforts focused particularly on monumental architecture in the A Group, the B Group, Caana (Figure 9), the Central Acropolis, and the South Acropolis. Following the discovery of basal stucco masks on Structure B5 and on the eastern flank of Structure B19, the TDP also made fiberglass replicas of the monuments so that these features would be openly visible to visitors at the site. Much of this research and conservation was also truly collaborative for it combined the efforts of archaeologists from the Caracol Archaeological Project with those of the TDP, the first major conservation project directed by Belizean archaeologists. This collaborative approach marked an important milestone in heritage preservation in Belize for, in many ways, it represented a significant move towards the decolonization of heritage management in the country, as argued for other venues [62,63]. More importantly, however, it served to demonstrate that far more can be accomplished in heritage management when national and international stakeholders work together and combine their efforts and resources [64,65]. At Caracol, the value of this approach is exemplified by these and several other joint operations at the site. In particular, the Caracol Archeological Project collaborated with the Tourism Development Project on carrying out more research in two archaeological complexes, Barrio and the South Acropolis, both areas that had previously been investigated. In both of these complexes the archaeological project excavated new rooms and buildings so that the entire complex could then be stabilized by the development project. Similar cooperation took place on the summit of Caana and in a residential complex referred to as the Raleigh Group.

Concurrent with the archaeological components of the conservation project, the TDP also invested considerable funds on infrastructural developments designed to preserve the site's monuments and to enhance visitor's experience at the site. These included the construction of modern bathroom facilities plus a large structure for housing and protecting Caracol's carved stone monuments. Additionally, as a result of the TDP funding package, the last 12 miles of the Caracol road-historically the worst section of the thruway-were paved, while other sections of the road were improved. The completion of the conservation and infrastructural components of the Tourism Development Project in 2004 led to a dramatic increase in visitation by both locals and foreigner visitors, and it also served to train many Belizeans in site conservation and heritage management. Today, many of the staff hired and trained by the TDP are now full-time members of the Belize Institute of Archaeology. 


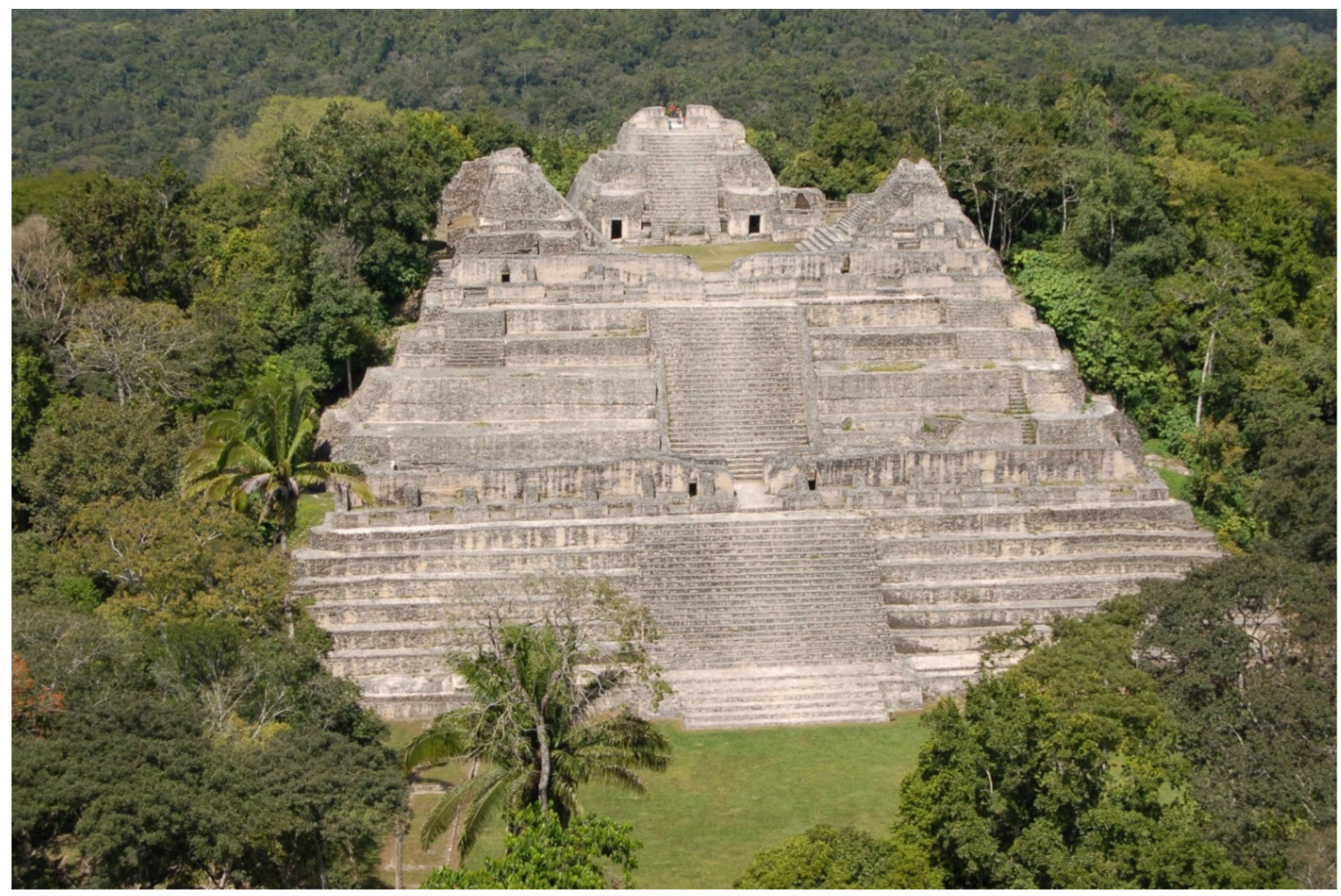

Figure 9. Caana, Caracol, Belize after stabilization by the TDP efforts.

\section{Caracol, Archaeology, and Stabilization: Other Stabilization-Northeast Acropolis}

Following the second set of stabilization efforts at Caracol, the Caracol Archaeological Project again embarked on settlement research for a number of years. However, the archaeological project then returned to the epicenter to carry out more investigations in the Northeast Acropolis, where research had originally been undertaken in 1994 and 1995. These investigations, carried out from 2009 to 2011, exposed the palace structure atop the northern substructure and the western and southwestern buildings. Rather than backfill these structures, the archaeological project opted to sponsor the stabilization of these buildings for tourism to encourage visitors to explore stabilized areas east of Caana that had been stabilized by the TDP. To accomplish this goal, the archaeological project hosted an Institute of Archaeology stabilization crew at the same time that project excavations were ongoing. As a result of these efforts, a walkway was constructed on the eastern side of Caana that climbed a stairway in the southwestern corner of the Northeast Acropolis and exited the southeastern corner of this complex. Additionally, Structures B31, B32, and B33 were all stabilized under the direction of the Institute of Archaeology in collaboration with the Caracol Archaeological Project. These investigations, like the previous ones, thus served both heritage management and archaeological research interests.

\section{Current and Future Development Plans and Issues}

Some aspects of the current development plans for the Caracol region are already under way. The unpaved road from the main Western Highway at Georgeville in Belize is being widened and paved-all the way into Caracol. While the last 12 miles of the road were paved in 2000, that road is currently rutted, pot-holed, and largely eroded to its underlying bedding. The new effort will formalize a road some 56 miles in length. This will facilitate touristic visits to Caracol and will undoubtedly lead to new stabilization efforts. A paved road will also provide access to the site by cruise-ship passengers that dock in Belize City, as it will make a day-trip by vehicle to Caracol a reality. This should 
substantially escalate the visitors to the site and increase the need to plan for the differentiation of visitor movement and access at the site to best preserve the archaeological and environmental resources.

The paved road, however, will also mean that new development and stabilization efforts will be possible- both because it will be easier to bring in supplies and to access other parts of the site. Currently, the epicenter can be toured in approximately three hours, but future plans would see the possibility of multi-day visits to the site. One potential plan would focus on causeway walks to impressive termini groups (nodes of monumental architecture that facilitated intra-city market exchange), permitting interested tourists to explore a series of residential complexes along the route. This would decrease concentrations of visitors in the epicenter and also meet the needs of tours focused on biological and natural resources

There is a strong desire on the part of the Belize Government to make Caracol a World Heritage Site. World Heritage status would not only raise national pride in Belize but would also help make Caracol more secure. Caracol is one of the oldest protected archaeological sites in Belize, having been established as a reserve by the then archaeological commissioner, A. Hamilton Anderson, and the British Colonial Government in 1958. The limits of the preserve only extend $5 \mathrm{~km}$ out from the site epicenter and do not encompass that actual ancient city. However, the archaeological reserve is located within another protected area, the Chiquibul Forest, and the activities within the Forest Reserve are exceedingly restricted. While Caracol remains a legally protected area by virtue of being located in both a protected archaeological reserve and a protected forest reserve, World Heritage status would even more firmly establish the priorities of site conservation as well as make more resources available to enhance security for the general area.

Learning from development at Tikal, Guatemala, there is currently no intent to develop hotels within the site itself. Future hotel development would likely take place in Douglas de Silva, some 22 miles from the site epicenter. It is projected that the only individuals residing in the epicenter of the site would be the site caretakers and park rangers, the rotating military patrols and tourism police, and the members of the archaeological project. The current museum, installed in 1999, will be updated and enlarged. At some point in time, a restaurant may open to provide lunch facilities and drinks for tourists, something currently not available.

Besides issues of modern services at the site-such as water (there is only rainwater capture and one functional ancient reservoir), electricity (there is only a generator or solar panels with no larger grid access), and phone service (there is no Belizean service, only Guatemalan service from certain parts of the site and atop certain pyramids) - there are a series of other concerns that need to be resolved in terms of heritage management. Looting of Maya sites has a long history within Central America because the beautiful objects that were created by the ancient peoples have significant modern monetary value [66,67]; this has created many ethical issues for modern Maya researchers [68-70] (see Balestrieri [71] for comparable ethical issues regarding looting in Classical Archaeology). Looting has been a consistent problem in Belize [30] and in the Caracol area [72]—as well as throughout much of the Maya area [73-76]. When the Caracol Archaeological Project started excavation at the site in 1985, there were a series of well-established looters' camps in the epicenter as well as substantial trenches on the Caana summit $[28,72]$. The magnitude of the problem led to a collaborative publication by the Caracol Archaeological Project and the Institute of Archaeology that sought to draw attention to broader issues related to looting [68]. During settlement pattern work in the 1980s, more camps, as well as open pits and tunnels, were recorded by surveyors, providing evidence of the looters often successful activities (it is clear that the looters uncovered tombs and caches in some of the termini groups and in numerous residential groups; see Figure 10). Newer technologies like lidar actively highlight the extensiveness of the looting [77,78], while raising a host of new ethical issues [79]. Looters have always been precocious and one of the legacies left by looters was the inside of a cigarette carton nailed to a tree at the end of the Pajaro-Ramonal Causeway in 1987, bearing a message in Spanish that let the archaeological project know that the looters were the archaeologists of that region and that the project was not welcome. 


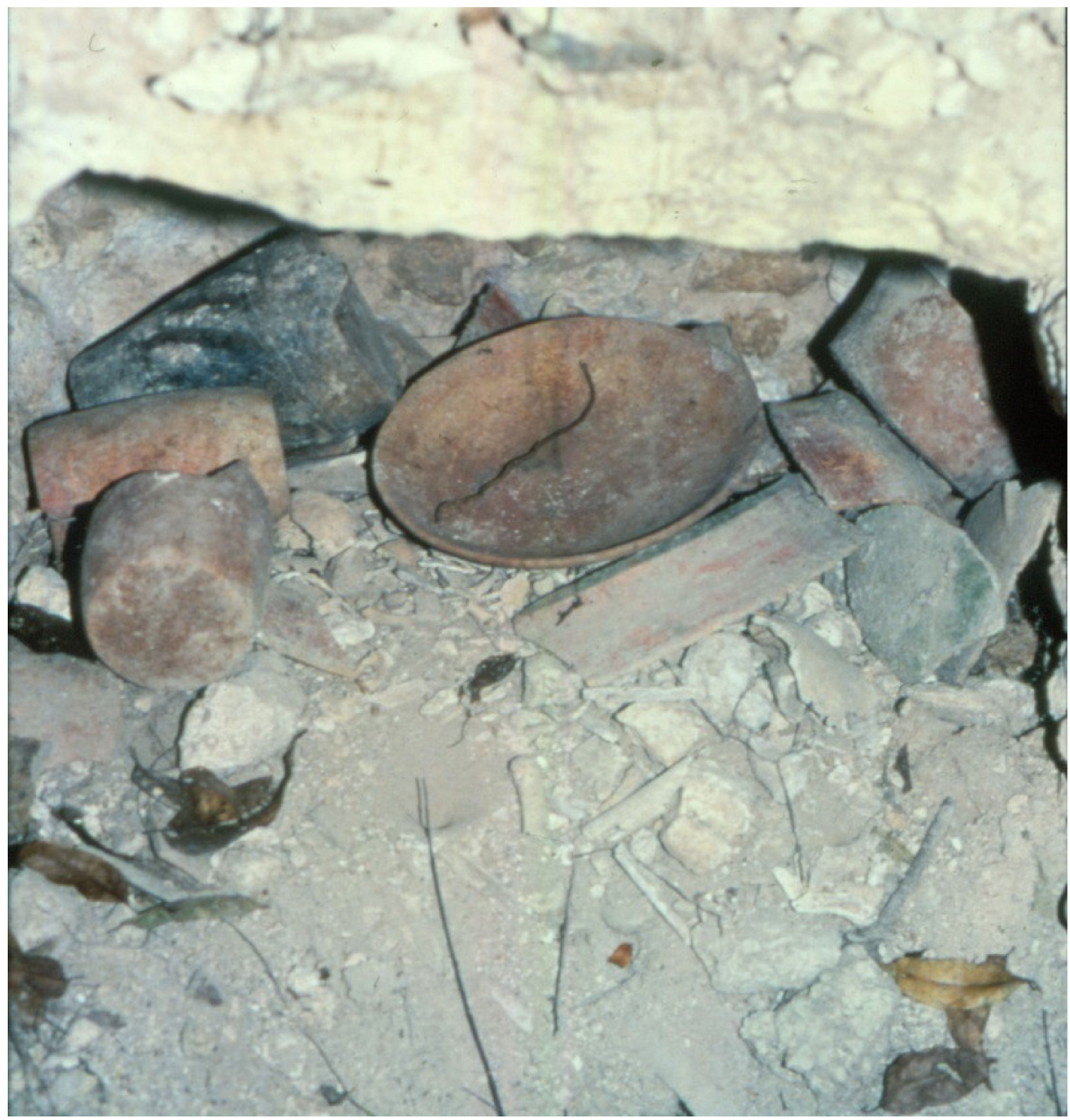

Figure 10. Artifactual materials left behind by looters at the Pajaro-Ramonal Terminus of Caracol.

Illegal excavation has continued throughout the years despite the best efforts by the Belizean military to patrol the immediate vicinity of the site. It has been accompanied over the years with an influx of people from across the Guatemalan border (only $4 \mathrm{~km}$ west of Caracol's epicenter) who combed through the Caracol jungle terrain in search of various items, including a wide variety of jungle resources other than archaeological materials. The first of these resources that was heavily collected was known as "shate"; the leaves of this plant were in high demand for flower arrangements throughout the developed world. The second wave of harvested items included hardwood trees. Illegal logging has been a perennial problem in the Caracol area, but in the last decade illicit loggers working at night have systematically removed entire species of trees, like mahogany and tropical cedar, for up to $10 \mathrm{~km}$ into Belize. They cut down the trees, carve out planks of wood with chainsaws, and then leave these planks to dry and then be hauled out by horseback at a later date across the border into Guatemala, where they are marketed. The final plant that has impacted looting and archaeological work is marijuana. Given that Guatemala and Belize have a border dispute over a 3-km wide stretch of land, many "farmers" have taken advantage of this no-person's land to plant marijuana crops 
and, in conjunction, to also loot ancient residential groups in this transitional zone. Thus, border control and management between Belize and Guatemala is one of the issues that must be resolved to promote site heritage management. Even though the populations in both countries have voted (in 2018 for Guatemala and 2019 for Belize) to have their long-standing border dispute [80] resolved by an international court, this resolution has not yet been effected. And, given the remoteness of Caracol, an international court decision may not actually solve the long-standing problems in and of themselves.

\section{Concluding Comments}

Within the last 50 years the role of archaeology has changed in most Central American countries from one more concerned with basic research to one where research has become intertwined with tourism and the economic benefits that accrue therein. Archaeology at Caracol began as basic research in its earliest phase in the middle of the twentieth century-an attempt to gain knowledge about a largely unknown part of the Maya area-but transitioned into a more comprehensive development plan that considered basic research, heritage management, and economic development. This led to collaborative efforts between the Belizean Institute of Archaeology and the Caracol Archaeological Project. These Belizean collaborations go beyond the site of Caracol; they were already in evidence with the Corozal Postclassic Project (1979-1985) that focused research on the Late Postclassic capital of Santa Rita Corozal in the Corozal District of Belize [81]; with the TDP, these collaborations also existed at Xunantunich and Lamanai. The collaboration between dirt archaeology, stabilization, and broader touristic goals at both Santa Rita Corozal [82-84] and Caracol [85-88] were highlighted in various Government of Belize publications. Other publications appeared in mainstream archaeology journals, one in particular being a joint statement on looting, collecting, and the protection of cultural heritage [68] (see also [70]). An even more recent collaboration builds on the earlier Santa Rita Corozal research, framing recent consolidation efforts in terms of the importance of the recovered archaeological data [89].

Collaborative efforts in heritage management-which combine the interests of researchers, local stakeholders, and national or world-wide heritage institutions-are critically important for the future success of archaeological research, conservation, and tourism development [64] (p. 76) [90,91]. This is particularly key in the Maya area, where many of the countries that make up the Mundo Maya are still in the process of developing their professional capacity to sustainably manage their cultural resources [64]. Importantly, these collaborative efforts serve to bring national and foreign colleagues together, as well as to help ensure that our interpretations and preservation efforts related to the past are conducted through teamwork rather than as independent efforts that ignore the interests of one group over the other [63,65] (pp. 173-181) [92,93]. Furthermore, these collaborative efforts also create "opportunities for finding common ground for dialogues about the goals of scientific research, publication, and conservation" [94], something particularly in evidence in Belize's annual archaeology symposium that occurred every year from 2003 to 2019 [33] (pp. 23-24) [95] (Belize's annual archaeology symposium was canceled for 2020 because of COVID-19).

Finally, it is important to note how Maya archaeology itself has changed in the last century. In his retrospective article on the importance of the Carnegie Institution of Washington's Uaxactun Project in the Peten District of Guatemala, Stephen Black [13] (p. 273) emphasized that the excavations at that site "served as a model for what might be called the dirt archaeologist's approach to Maya sites" in that they "were not constrained by any concern for preserving the site". Even though destructive, the results of this research generated archaeological data that was crucial for the development of Maya archaeology and that is still used today (see especially information on the site's ceramics $[96,97]$ and information on Group E and its astronomical significance [34,98]. Black [13] (p. 273) contrasted the Uaxactun research with that at Chichen Itza, which he viewed as spawning "a preservationist approach to Maya sites which has contributed little to Maya archaeology beyond a corpus of reconstructed monumental architectures". We strongly believe that the contrast between dirt archaeology and preservationist approaches is no longer valid. We have always felt that the two approaches to Maya research-research 
archaeology and a preservationist approach—should be conjoined. Because of the long-standing partnership between the archaeological project and the Belize Institute of Archaeology, excavations at Caracol have not only focused on conserving areas important to site preservation and eco-development, but also on carrying out more intensive research in areas that otherwise might have seen limited archaeological sampling because of the need to engage with heritage management. In this vein, we hope that the long-term research and stabilization efforts at Caracol, Belize have served as a model for how this can be successfully accomplished.

Author Contributions: A.F.C., D.Z.C., J.M.M., J.J.A. and A.S.Z.C. participated in the written production of this article. All authors have read and agreed to the final version of the manuscript.

Funding: The research at Caracol has been funded by the Ahau Foundation, the Alphawood Foundation, the Dart Foundation, the Foundation for the Advancement of Mesoamerican Studies Inc., the Geraldine and Emory Ford Foundation, the Government of Belize, the Harry Frank Guggenheim Foundation, the National Aeronautics and Space Agency, the National Science Foundation, the Stans Foundation, the United States Agency for International Development, and private donations to the various university foundations.

Acknowledgments: None of the research reported here would have been possible without the support of the Belize Institute of Archaeology (IoA; previously the Belize Department of Archaeology), the assistance of project members and staff (see http://www.caracol.org for a listing of these individuals; all staff are listed by their assigned project numbers and all other participants in the various field seasons are usually listed in Table 1 in each of the annual field reports available at this website), and the various academic sponsors of the Caracol Archaeological Project-including the University of Central Florida, the University of Nevada (Las Vegas), Claremont Graduate University, and Pomona College. The authors thank the six anonymous reviewers for their comments on an earlier version of this article.

Conflicts of Interest: The authors declare no conflict of interest.

\section{References}

1. de Sahagun, B.; Arthur, J.O.A.; Dibble, C.E. Florentine Codex: General History of the Things of New Spain; University of Utah Press: Salt Lake City, UT, USA, 1970.

2. Tozzer, A.M. Landa's Relacion De Las Cosas de Yucatan: A Translation; Peabody Museum of Archaeology and Ethnology, Harvard University: Cambridge, MA, USA, 1941; p. 18.

3. Chamberlain, R.S. The Conquest and Colonization of the Yucatan: 1517-1550; Octagon Books: New York, NY, USA, 1966.

4. Chase, D.Z. Social and Political Organization in the Land of Cacao and Honey: Correlating the Archaeology and Ethnohistory of the Postclassic Lowland Maya. In Late Lowland Maya Civilization: Classic to Postclassic; Sabloff, J.A., Andrews, E.W.V., Eds.; University of New Mexico Press: Albuquerque, NM, USA, 1986; pp. 347-377.

5. Farriss, N.M. Maya Society under Colonial Rule: The Collective Enterprise of Survival; Princeton University Press: Princeton, NJ, USA, 1984.

6. Amrhein, L.M. An Iconographic and Historic Analysis of Terminal Classic Maya Phallic Imagery (Yucatan). Ph.D. Thesis, Virginia Commonwealth University, Richmond, VA, USA, 2001.

7. Ardren, T.; David, R.H. The Unusual Sculptures of Telantunich, Yucatan: Phalli and the Concept of Masculinity among the Ancient Maya. Camb. Archaeol. J. 2006, 16, 7-25. [CrossRef]

8. Thompson, J.E.S. Maya History and Religion; University of Oklahoma Press: Norman, OK, USA, 1970.

9. Bueno, C. The Pursuit of Ruins: Archeology, History, and the Making of Modern Mexico; University of New Mexico Press: Albuquerque, NW, USA, 2016.

10. Acosta, J.R. Archaeological Explorations in Teotihuacan. Artes Mexico Teotihuacan Lugar Dioses 1970, 134, 11-18.

11. Peniche, M.N. Arqueologia Patria: Mexican Archaeology and the Nation-Building Process during the Nineteenth Century. In Constructing Legacies of Mesoamerica: Archaeological Practice and the Politics of Heritage in and Beyond Mexico, AP3A Paper 25; Anderson, D.S., Clark, D.J., Anderson, J.H., Eds.; American Anthropological Association: Arlington VA, USA, 2015; pp. 19-25.

12. Anderson, D.S.; Dylan, J.C.; Anderson, H.J. (Eds.) Constructing Legacies of Mesoamerica: Archaeological Practice and the Politics of Heritage in and Beyond Mexico. AP3A Paper 25; American Anthropological Association: Arlington, VA, USA, 2015.

13. Black, S.L. The Carnegie Uaxactun Project and the Development of Maya Archaeology. Anc. Mesoam. 1990, 1, 257-276. [CrossRef] 
14. Smith, A.L. Uaxactun: A Pioneering Excavation in Guatemala; Addison-Wesley Module in Anthropology 40, Addison-Wesley: Boston, MA, USA, 1973.

15. Casteneda, Q.E. In the Museum of Maya Culture: Touring Chichen Itza; University of Minnesota Press: Minneapolis, MN, USA, 1996.

16. Tozzer, A.M. Chichen Itza and Its Cenote of Sacrifice; Memoirs of the Peabody Museum of Anthropology Volumes 11 and 12, Harvard University: Cambridge, MA, USA, 1957.

17. Kowalski, J.K.; Cynthia, K.G. (Eds.) Twin Tollans: Chichen Itza, Tula, and the Epiclassic to Early Postclassic Mesoamerican World; Dumbarton Oaks: Washington, DC, USA, 2007.

18. Cobos, R. The Relationship between Tula and Chichen Itza: Influences or Interactions. In Lifeways in the Northern Maya Lowlands: New Approaches to Archaeology in the Yucatan Peninsula; Mathews, J.P., Morrison, B.A., Eds.; University of Arizona Press: Tucson, AZ, USA, 2006; pp. 173-183.

19. Augusto, M.-M. Archaeological Buildings: Restoration or Misrepresentation. In Falsifications and Misreconstructions in Pre-Columbian Art; Bensen, E.P., Boone, E.H., Eds.; Dumbarton Oaks: Washington, DC, USA, 1982; pp. 125-141.

20. Smith, A.L. Uaxactun, Guatemala: Excavations of 1931-1937; Publication 568, Carnegie Institution of Washington: Washington, DC, USA, 1950.

21. Weeks, J.M.; Jane, A.H.; Charles, G. (Eds.) Piedras Negras Archaeology, 1931-1939; University of Pennsylvania Museum Press: Philadelphia, PA, USA, 2005.

22. Houston, S.D.; Hector, E. The Piedras Negras Project, 1997 Season. Available online: https://famsi.org/reports/ 96005/index.html (accessed on 3 May 2020).

23. Coe, W.R. Excavations in the Great Plaza, North Terrace, and North Acropolis of Tikal, Tikal Report 14; University Museum Monograph 61; The University Museum, University of Pennsylvania: Philadelphia, PA, USA, 1990.

24. Rainey, F.; Alfred, K., II; Linton, S.; William, R.C. Reply to Berlin. Am. Antiq. 1967, 32, 242-244. [CrossRef]

25. Berlin, H. The Destruction of Structure 5D-33-1st at Tikal. Am. Antiq. 1967, 32, 236-241. [CrossRef]

26. Thompson, J.E. A Third-Party Comment. Am. Antiq. 1967, 32, 244. [CrossRef]

27. Chase, A.F.; Diane, Z.C. Ancient Maya Architecture and Spatial Layouts: Contextualizing Caana at Caracol, Belize. Res. Rep. Belizean Archaeol. 2017, 14, 13-22.

28. Chase, A.F.; Diane, Z.C. Investigations at the Classic Maya City of Caracol, Belize: 1985-1987, Monograph 3; Pre-Columbian Art Research: San Francisco, CA, USA, 1987.

29. Chase, A.F.; Diane, Z.C. The Royal Court of Caracol, Belize: Its Palaces and People. In Royal Courts of the Ancient Maya: Volume 2: Data and Case Studies; Inomata, T., Houston, S.D., Eds.; Westview Press: Boulder, CO, USA, 2001; pp. 102-137.

30. Topsey, H.W. New Developments in the Cultural Resource Management of Belize. In Fourth Palenque Round Table, 1980; Robertson, M.G., Benson, E.P., Eds.; Pre-Columbian Art Research Institute: San Francisco, CA, USA, 1985; pp. 281-284.

31. Chase, D.Z.; Arlen, F.C. (Eds.) Studies in the Archaeology of Caracol, Belize; Monograph 7, Pre-Columbian Art Research Institute: San Francisco, CA, USA, 1994.

32. Chase, D.Z.; Chase, A.F. Caracol, Belize, and Changing Perceptions of Ancient Maya Society. J. Archaeol. Res. 2017, 25, 185-249. [CrossRef]

33. Chase, A.F.; Diane, Z.C. Central Belize and the Development of Maya Archaeology: A Critical Assessment. Res. Rep. Belizean Archaeol. 2019, 16, 3-19.

34. Chase, A.F.; Diane, Z.C. E Groups and the Rise of Complexity in the Southeastern Maya Lowlands. In Maya E Groups: Calendars, Astronomy, and Urbanism in the Early Lowlands; Freidel, D.A., Chase, A.F., Dowd, A., Murdock, J., Eds.; University of Florida Press: Gainesville, FL, USA, 2017; pp. 31-71.

35. Chase, A.F.; Diane, Z.C. Final Moments: Contextualizing On-Floor Archaeological Materials from Caracol, Belize. Anc. Mesoam. 2020, 31,77-87. [CrossRef]

36. Chase, A.F.; Diane, Z.C. Classic Maya Warfare and Settlement Archaeology at Caracol, Belize. Estud. Cult. Maya 2002, 22, 33-51.

37. Chase, D.Z.; Arlen, F. Chase. Que no nos Cuentan los Jeroglificos: Arqueologia e Historia en Caracol, Belice. Mayab 2008, 20, 93-108.

38. Chase, A.S.Z. Urban Structure and Governance at Caracol, Belize. Ph.D. Thesis, School of Human Evolution and Social Change, Arizona State University, Tempe, AZ, USA, 2021. 
39. Chase, A.F.; Chase, D.Z. Status and Power: Caracol, Teotihuacan, and the Early Classic Maya World. Res. Rep. Belizean Archaeol. 2011, 8, 3-18.

40. Chase, A.S.Z. Districting and Urban Services at Caracol, Belize: Intrasite Boundaries in an Evolving Maya Cityscape. Res. Rep. Belizean Archaeol. 2016, 13, 25-28.

41. Chase, A.F.; Diane, Z.; Adrian, S.Z.C. The Maya City of Caracol, Belize: The Integration of an Anthropogenic Landscape. In The Maya World; Hutson, S., Ardren, T., Eds.; Routledge Press: London, UK, 2020; pp. 344-363.

42. Chase, A.F.; Diane, Z.; Adrian, S.Z.C. Caracol's Impact on the Landscape of the Classic Period Maya: Urbanism and Complex Interaction in a Tropical Environment. In Approaches to Monumental Landscapes of the Ancient Maya; Houk, B.A., Arroyo, B., Powis, T.G., Eds.; University Press of Florida: Gainesville, FL, USA, 2020; pp. 109-130.

43. Helmke, C.; Arlen, F.C.; Diane, Z.C. Another Look at Stela 2 of Caracol, Belize. Mexicon 2019, 41, 97-104.

44. Stuart, D.; The Origin of Copan's Founder. Maya Decipherment: Ideas on Ancient Maya Writing and Iconography. Available online: https://mayadecipherment.com/2007/06/25/ (accessed on 27 March 2007).

45. Chase, A.F.; Diane, Z.C. The Materialization of Classic Period Maya Warfare: Caracol Stranger-Kings at Tikal. In A Forest of History: The Maya after the Emergence of Divine Kingship; Stanton, T.W., Brown, M.K., Eds.; University Press of Colorado: Boulder, CO, USA, 2020; pp. 20-48.

46. Chase, A.F.; Diane, Z.C. The Investigation of Classic Period Maya Warfare at Caracol, Belize. Mayab 1989, 5, 5-18.

47. Chase, A.F.; Diane, Z.C. Symbolic Egalitarianism and Homogenized Distributions in the Archaeological Record at Caracol, Belize: Method, Theory, and Complexity. Res. Rep. Belizean Archaeol. 2009, 6, 15-24.

48. Chase, A.F. Elites and the Changing Organization of Classic Maya Society. In Mesoamerican Elites: An Archaeological Assessment; Chase, D.Z., Chase, A.F., Eds.; University of Oklahoma Press: Norman, OK, USA, 1992; pp. 30-49.

49. Chase, A.F.; Diane, Z.C. A Mighty Maya Nation: How Caracol Built an Empire by Cultivating its Middle Class. Archaeology 1996, 49, 66-72.

50. Chase, A.F.; Diane, Z.C.; Richard, T.; Jacob, M.H.; Adrian, S.Z.C. Markets among the Ancient Maya: The Case of Caracol, Belize. In The Ancient Maya Marketplace: The Archaeology of Transient Space; King, E., Ed.; University of Arizona Press: Tucson, AZ, USA, 2015; pp. 226-250.

51. Chase, D.Z.; Arlen, F.C. Ancient Maya Markets and the Economic Integration of Caracol, Belize. Anc. Mesoam. 2014, 25, 239-250. [CrossRef]

52. Chase, D.Z.; Arlen, F.C. The Ancient Maya Economic Landscape of Caracol, Belize. In The Real Business of Ancient Maya Economies: From Farmers' Fields to Rulers' Realms; Masson, M., Freidel, D.A., Demarest, A., Eds.; University Press of Florida: Gainesville, FL, USA, 2020; pp. 231-248.

53. Chase, A.S.Z. Beyond Elite Control: Maya Water Management at the Site of Caracol, Belize. Bachelor's Thesis, Departments of Archaeology and Computer Science, Harvard University, Cambridge, MA, USA, 2012.

54. Chase, A.S.Z. Beyond Elite Control: Residential Reservoirs at Caracol, Belize. WIREs Water 2016, 3, 885-897. [CrossRef]

55. Chase, A.F.; Diane, Z.C. Urbanism and Anthropogenic Landscapes. Annu. Rev. Anthropol. 2016, 45, 361-376. [CrossRef]

56. Chase, A.F.; Diane, Z.C. Interpreting Form and Context: Ceramic Subcomplexes at Caracol, Nohmul, and Santa Rita Corozal, Belize. In Ancient Maya Pottery: Classification, Analysis, and Interpretation; Aimers, J., Ed.; University Press of Florida: Gainesville, FL, USA, 2013; pp. 46-73.

57. Chase, A.F.; Diane, Z.C. Foreward. In Approaches to Monumental Landscapes of the Ancient Maya; Houk, B.A., Arroyo, B., Powis, T.G., Eds.; University Press of Florida: Gainesville, FL, USA, 2020.

58. Fash, W.L.; Ricardo, N.F. Copan: The History of an Ancient Maya Kingdom. In Copan: The History of an Ancient Maya Kingdom; Andrews, E.W., Fash, W.L., Eds.; SAR Press: Santa Fe, NM, USA, 2005; pp. 1-30.

59. Anderson, A. Hamilton Recent Discoveries at Caracol Site, British Honduras. In Proceedings of the 32nd International Congress of Americanists, Copenhagen, Denmark, 8-14 August 1956; ICA: Copenhagen, Denmark, 1958; pp. 494-499.

60. Anderson, A.H. More Discoveries at Caracol, British Honduras. Actas del 33rd Congreso Internacional des Americanistas, San Jose, Costa Rica, 20-27 July 1958; Lehmann: San Jose, Costa Rica, 1959; pp. 211-218.

61. Means, B.K. Labouring in the Fields of the Past: Geographic Variation in New Deal Archaeology Across the Lower 48 United States. Bull. Hist. Archaeol. 2015, 25, 7. [CrossRef] 
62. Castaneda, Q.E.; Mathews, J.P. Archaeology Meccas of Tourism: Exploration, Protection, and Exploitation. In Tourism and Archaeology: Sustainable Meeting Grounds; Walker, C., Carr, N., Eds.; Left Coast Press: Walnut Creek, CA, USA, 2013; pp. 37-64.

63. Rodriguez, Timoteo. Conjunctures in the Making of an Ancient Maya Archaeological Site. In Ethnographies of Archaeological Practice: Cultural Encounters \& Material Transformations; Edgeworth, M., Ed.; Altamira Press: Walnut Creek, CA, USA, 2006; pp. 161-172.

64. Awe, J.J. The Archaeology of Belize in the 21st Century. In Oxford Handbook of Mesoamerican Archaeology; Nichols, D.L., Pool, C.A., Eds.; Oxford University Press: Oxford, UK, 2012; pp. 69-82.

65. Carman, J. Archaeological Resource Management: An International Perspective; Cambridge University Press: New York, NY, USA, 2015.

66. Coe, M.C. From Huaquero to Connoisseur: The Early Market in Precolumbian Art. In Collecting the Pre-Columbian Past; Boone, E.H., Ed.; Dumbarton Oaks: Washington, DC, USA, 1993; pp. 271-290.

67. Elia, R.J. Looting, Collecting, and the Destruction of Archaeological Resources. Nonrenewable Resour. 1997, 6, 85-98. [CrossRef]

68. Chase, A.F.; Diane, Z.C.; Harriot, W.T. Archaeology and the Ethics of Collecting. Archaeology 1988, 41, 56-60.

69. Matsuda, D. The Ethics of Archaeology, Subsistence Digging, and Artifact Looting in Latin America. Int. J. Cult. Prop. 1998, 7, 87-97. [CrossRef]

70. Pendergast, D.; Elizabeth, G. The Battle for the Maya Past: The Effects of International Looting and Collecting in Belize. In The Ethics of Collecting Cultural Property: Whose Culture? Whose Property? Messenger, P.M., Ed.; University of New Mexico Press: Albuquerque, NM, USA, 1990; pp. 51-60.

71. Balestrieri, B.A.B. Field Archaeologists as Eyewitnesses to Site Looting. Arts 2018, 7, 48. [CrossRef]

72. Chase, A.F.; Diane, Z.C. Glimmers of a Forgotten Realm: Maya Archaeology at Caracol, Belize; University of Central Florida: Orlando, FL, USA, 1987.

73. Coggins, C.C. Illicit Traffic of Pre-Columbian Antiquities. Art J. 1969, 29, 94-98. [CrossRef]

74. Miller, M.E. The Market for Mesoamerica: Reflections on the Sale of Pre-Columbian Antiquities; Cara, G.T., Donna, T., Eds.; University Press of Florida: Gainesville, FL, USA, 2019.

75. Tremain, C.G.; Donna, Y. (Eds.) The Market for Mesoamerica: Reflections on the Sale of Pre-Columbian Antiquities; University Press of Florida: Gainesville, FL, USA, 2019.

76. Yates, D. Illicit Cultural Property from Latin America: Looting, Trafficking, and Sale. In Countering Illicit Traffic in Cultural Goods: The Global Challenges of Protecting the World's Heritage; Demaris, F., Ed.; International Council of Museums: Paris, French, 2015; pp. 33-45.

77. Chase, A.F.; Chase, D.Z.; Weishampel, J.F.; Drake, J.; Shrestha, R.L.; Slatton, K.C.; Awe, J.J.; Carter, W.E. Airborne LiDAR, archaeology, and the ancient Maya landscape at Caracol, Belize. J. Archaeol. Sci. 2011, 38, 387-398. [CrossRef]

78. Canuto, M.A.; Estrada-Belli, F.; Garrison, T.G.; Houston, S.D.; Acuña, M.J.; Kováč, M.; Phillipe, N.; Luke, A.T.; Cyril, C.; David, C.; et al. Fernandez-Diaz, and Ramesh Shrestha. Ancient Lowland Maya Complexity as Revealed by Airborne Laser Scanning of Northern Guatemala. Science 2018, 361, 1355. [CrossRef]

79. Chase, A.S.Z.; Chase, D.; Chase, A. Ethics, New Colonialism, and Lidar Data: A Decade of Lidar in Maya Archaeology. J. Comput. Appl. Archaeol. 2020, 3, 51-62. [CrossRef]

80. Perez, A.; Chin-Ta, C.; Afero, F. Belize-Guatemala Territorial Dispute and its Implications for Conservation. Trop. Conserv. Sci. 2009, 2, 11-24. [CrossRef]

81. Chase, D.Z.; Arlen, F.C. A Postclassic Perspective: Excavations at the Maya Site of Santa Rita Corozal, Belize; Monograph 4, Pre-Columbian Art Research Institute: San Francisco, CA, USA, 1988.

82. Chase, A.F. Major Find from Maya Era Unearthed. New Belize 1980, 10, $2-3$.

83. Chase, D.Z.; Arlen, F.C. Santa Rita Corozal: A Rich Past Leads to a Rich Heritage. New Belize 1984, 14, $13-14$.

84. Chase, D.Z.; Arlen, F.C. Refining Maya Prehistory: Archaeology at Santa Rita Corozal. New Belize 1985, 15, $14-17$.

85. Chase, A.F.; Diane, Z.C. Caracol: Belize's National Treasure. New Belize 1986, 16, 15-16.

86. Chase, A.F.; Diane, Z.C. Mixing Archaeology and Touristic Development at Caracol. Belize Today 1991, 5, 12-13.

87. Chase, A.F.; Diane, Z.C. Tombs and Texts: New Discoveries at Caracol. Belize Today 1993, 7, 46-49.

88. Chase, A.F.; Diane, Z.C. The Causeways of Caracol. Belize Today 1996, 10, 31-32.

89. Awe, J.J.; Jorge, C.; Arlen, F.C.; Diane, Z.C. Archaeological Investigations and Conservation at Santa Rita Corozal: Results of the 2012-2013 Belize Institute of Archaeology Project. Res. Rep. Belizean Archaeol. 2020, 17. (in press). 
90. Awe, J.J. Cultural Resource Management in Belize. In Cultural Resource Management: A Collaborative Primer for Archaeologists; King, T.F., Ed.; Berghahn Books: New York, NY, USA, 2020; pp. 117-125.

91. Silverman, H. Touring Ancient Times: The Present and Presented Past in Contemporary Peru. Am. Anthr. 2002, 104, 881-902. [CrossRef]

92. Ardren, T. Conversations about the Production of Knowledge and Community Museums at Chunchucmil and Kochol, Yucatan, Mexico. World Archeol. 2002, 34, 379-400. [CrossRef]

93. Pinter, T.L. Heritage Tourism and Archaeology: Critical Issues. SAA Archaeol. Rec. 2005, 5, 9-11.

94. Walker, C. Promoting While Preserving: The Challenge of Heritage Tourism. SAA Archaeol. Rec. 2005, 5, $23-25$.

95. Morris, J.M.; Jaime, J.A.; Shrilyne, J. Introduction and Synthesis of the 2003 Belizean Archaeology Symposium. Res. Rep. Belizean Archaeol. 2004, 1, 1-10.

96. Smith, R.E. Ceramic Sequence at Uaxactun, Guatemala.; Middle American Research Institute, Tulane University: New Orleans, LA, USA, 1955; Volume 2.

97. Willey, C.R.; Patrick, T.C.; Richard, E.W.A. A Report from the 1965 Guatemala city Conference. Am. Antiq. 1967, 32, 289-315.

98. Ricketson, O.; Edith, R. Uaxactún, Guatemala, Group E, 1926-1931, Publication 477; Carnegie Institute of Washington: Washington, DC, USA, 1937.

(C) 2020 by the authors. Licensee MDPI, Basel, Switzerland. This article is an open access article distributed under the terms and conditions of the Creative Commons Attribution (CC BY) license (http://creativecommons.org/licenses/by/4.0/). 